\title{
Erratum to prevalence of hyperthyroidism with hypercalcemia in Xindu district and the efficacy of vitamin D3 treatment in these patients: a randomized trial
}

\section{Editorial Office}

Annals of Palliative Medicine

Correspondence to: Editorial Office. Annals of Palliative Medicine. Email: apm@amepc.org.

Submitted Nov 17, 2021. Accepted for publication Nov 21, 2021.

doi: 10.21037/apm-2021-10

View this article at: https://dx.doi.org/10.21037/apm-2021-10

Erratum to: Ann Palliat Med 2021;10:9640-9

This article (1) that appeared on Page: 9640-9649, Vol 10, No 9 Issue of the Annals of Palliative Medicine (APM), unfortunately contained some mistakes on page 9644 in the second paragraph of the discussion section. Namely, "a total of 134 patients with hyperthyroidism" should be "a total of 184 patients with hyperthyroidism" and "18 of whom were associated with hypercalcemia (accounting for 13.43\%)" should be "36 of whom were associated with hypercalcemia (accounting for $19.57 \%)$ ".

The related sentence after correction is presented as follows:

"In our study, we observed a total of 184 patients with hyperthyroidism, 36 of whom were associated with hypercalcemia (accounting for 19.57\%)."

The authors regret the errors.

Click here to view the updated version of the article.

Open Access Statement: This is an Open Access article distributed in accordance with the Creative Commons AttributionNonCommercial-NoDerivs 4.0 International License (CC BY-NC-ND 4.0), which permits the non-commercial replication and distribution of the article with the strict proviso that no changes or edits are made and the original work is properly cited (including links to both the formal publication through the relevant DOI and the license). See: https://creativecommons.org/licenses/by-nc$\mathrm{nd} / 4.0 \%$.

\section{References}

1. Mei X, Zeng J, Dai WX, et al. Prevalence of hyperthyroidism with hypercalcemia in Xindu district and the efficacy of vitamin D3 treatment in these patients: a randomized trial. Ann Palliat Med 2021;10:9640-9.

Cite this article as: Editorial Office. Erratum to prevalence of hyperthyroidism with hypercalcemia in Xindu district and the efficacy of vitamin D3 treatment in these patients: a randomized trial. Ann Palliat Med 2021;10(12):13037. doi: 10.21037/apm2021-10 